\title{
Chloromethyl Methyl Ether
}

National Cancer Institute

\section{Source}

National Cancer Institute. Chloromethyl Methyl Ether. NCI Thesaurus. Code C44355.

A colorless, flammable, carcinogenic liquid with a highly irritating odor. Chloromethyl methyl ether is used in the synthesis of chloromethylated compounds, as an alkylating agent, and as a solvent in the manufacture of water repellents, ion-exchange resins, and industrial polymers. Exposure to its vapors causes severe irritation of the skin, eyes, mucous membranes, respiratory tract as well as pulmonary edema, pneumonia and lung cancer (mainly small-cell type) in humans. Chloromethyl methyl ether is a known human carcinogen. $(\mathrm{NCl05})$ 